\title{
Effect of fasting on self-feeding activity in juvenile sea bass (Dicentrarchus labrax)
}

\author{
David Benhaïm ${ }^{a}{ }^{*}$, Marie-Laure Bégout ${ }^{\mathrm{b}}$, Samuel Péan ${ }^{\mathrm{b}}$, Blandine Brisset ${ }^{\mathrm{b}}$, Didier Leguay ${ }^{\mathrm{b}}$, \\ Béatrice Chatain $^{\mathrm{c}}$
}

\author{
a LERMA, INTECHMER/CNAM, BP 324, 50103 Cherbourg Cedex, France \\ ${ }^{b}$ Ifremer, Place Gaby Coll, BP 7, 17137 L'Houmeau, France \\ c Station Expérimentale d'Aquaculture Ifremer, Laboratoire de Recherche Piscicole de Méditerranée, Chemin de \\ Maguelone, 34250 Palavas-Les-Flots, France
}

\author{
*: Corresponding author : David Benhaïm, Tel.: +3302338873 38 ; fax: +330233 887339 \\ email address : david.benhaim@cnam.fr
}

\begin{abstract}
:
In various experiments under self-feeding conditions, sea bass groups could be divided into three categories regarding feeder actuation: high, low and zero-triggering fish. In all cases few hightriggering fish were responsible for a high percentage of the feed delivery. A question was raised about the role played by feeding motivation in such high-triggering status acquisition. It was approached by applying a 3-week fasting period in order to induce similar negative specific growth rate (SGR) in two groups of fish of similar mean weight but with either a low or a high coefficient of variation for weight $\left(\mathrm{CV}_{\mathrm{w}}\right)\left(\mathrm{T}_{\text {low: }}: \mathrm{CV}_{\mathrm{w}} \sim 11 \%, 3\right.$ tanks of 60 fish each; $\mathrm{T}_{\text {high: }} \mathrm{CV}_{\mathrm{w}} \sim 20 \%, 3$ tanks of 60 fish each). These groups were created to test the consistency of behavioural responses in two different contexts (i.e. two population size-distributions). During the follow-up period of 40 days, the group level feed-demand behaviour was not strongly modified by the fasting period and there were no differences between $T_{\text {low }}$ and $T_{\text {high }}$ groups. Complete growth compensation was the same in all tanks as observed at the end of the experiment. At the individual level, high-triggering fish were exactly the same individuals before and after the fasting period. Up to four high-triggering fish could be observed according to the tank and when several fish were performing high-triggering activity, their rankings were sometimes reversed after the fasting period. High-triggering fish increased their activity levels after the fasting period showing behavioural plasticity. High-triggering status could neither be explained by an initial lower SGR nor a sex effect, nor by any of the measured physiological blood parameters. Thus, individual's triggering activity levels could be related to personality and/or metabolic traits but further research is required to confirm this assumption.
\end{abstract}

Keywords : Personality ; Plasticity ; Feeding-behaviour ; Self-feeder ; Social structure 


\section{Introduction}

Self-feeding systems have been primarily developed to allow fish to obtain food according to their energy and nutrition requirements (Brännäs and Alanärä, 1993; Paspatis and Boujard, 1996; Sánchez-Vázquez et al., 1998; Sánchez-Vázquez et al., 1999; Yamamoto et al., 2000a; Yamamoto et al., 2000b) at preferred feeding times (Boujard and Leatherland, 1992; Sánchez-Vázquez et al., 1995; Boujard et al., 1996; Heilman and Spieler, 1999). In the recent years, when coupled with a PIT tag detection antenna, they opened up new research perspectives. They contributed to better understand the individual behaviours of fish living in groups (Alanärä and Brännäs, 1993; Covès et al., 2006). For example, dominance hierarchies have been described in rainbow trout, Oncorhynchus mykiss (Alanärä and Brännäs, 1993; 1996 ; Alanärä et al., 1998) and arctic charr, Salvelinus alpinus (Brännäs and Alanärä, 1993; Alanärä and Brännäs, 1996 ) reared under self-feeding conditions.

Numerous studies using this device concerned European sea bass, Dicentrarchus labrax, a commercially important species in the Mediterranean that has demonstrated a great ability and high plasticity to use such systems (Covès et al., 1998; Rubio et al., 2004). In this species, an intriguing individual specialization exists when using self-feeders with three triggering categories coexisting: high (HT), low (LT) and zero-triggering (ZT) fish (Covès et al., 2006; Di-Poï et al., 2007; Millot et al., 2008; Millot and Bégout, 2009). In small populations composed of 50 to 100 fish, whatever the experimental conditions, the same pattern is always observed: HT fish are very few with only one or two animals being responsible for $80 \%$ of the triggering activity under a reward regime of 1 or 2 pellets per individual given after each actuation (Covès et al., 2006) or two or three fish responsible of about $45 \%$ of the triggering activity under a reward regime equivalent to 1 pellet per individual (Millot et al., 2008). On the other hand, the ZT status would be attributed to fish that never actuate the device (Covès et al., 2006; Millot et al., 2008) or less than $4 \%$ of the time or if they perform a mean triggering activity lower than once a day (Di-Poï et al., 2007). This ZT category represented about $10 \%$ of the population (Covès et al., 2006), the rest being composed of individuals that seldom actuated the trigger (LT), (Covès et al., 2006): $\leq 25 \%$ of actuations (Millot et al., 2008), 4 to $15 \%$ (DiPoï et al., 2007), 0 to 30\% (Covès et al., 2006). This individual specialization in three categories has 
been shown to be homogenous and stable in time over 200 days (Millot et al., 2008) with HT fish keeping their status during 60 days on average (Millot and Bégout, 2009). These authors showed that an HT fish that looses its status rarely recovers it, and becomes LT. They also hypothesized that the frequent change of HT fish in a tank could be regarded as the consequence of an imbalance group social structure (Millot, 2008), pointing out that changes occurred at the time of stressful events or spontaneously but without changing the overall population composition (Millot, 2008; Millot and Bégout, 2009). The characteristics of HT, LT or ZT fish could be summarised as followed:

- $\quad$ None of these fish showed differential access to delivered food whatever the category they belong to (Covès et al., 2006) and there was no clear evidence of a link between sex and food demand i.e. HT fish are either females or males (Covès et al., 2006).

- In most cases, the three categories exhibited no difference in mean initial or final weights or in mean specific growth rate (Covès et al., 2006; Di-Poï et al., 2007; Di-Poï et al., 2008).

- The serotonergic turnover of LT and ZT individuals is higher than the HT's one indicating that they could be under social stress due to the high activity of HT individuals (Di-Poï et al., 2007) or that they are subordinate fish (Winberg and Nilsson, 1993).

Finally, Millot et al. (2008) pointed out an interesting result from a long term experiment where the future HT individuals had negative specific growth rate at the beginning of their active period. These authors hypothesized that fish with a negative growth might be searching more for pellets and/or spent more time in the feeding zone i.e. had a higher feeding motivation, which in turn, may enhance the self-feeder learning process and hence its actuation. Another hypothesis would be that HT specialization could be underpinned by personality traits.

Animal personality traits can be defined as behavioural tendencies that affect behaviour in different contexts, vary across the individuals in a given population, and are consistent within individuals across time (Sih et al., 2004; Réale et al., 2007). Among personality traits, shyness or boldness have been described in several fish species: sunfish, Lepomis gobbosus (Coleman and Wilson, 1998); guppies, Poecilia reticulata (Godin and Dugatkin, 1996); rainbow trout (Werner and Anholt, 1993; Lima et al., 1998); sea bass (Millot et al., 2009). In rainbow trout, boldness could be 
associated to learning abilities (Sneddon, 2003). As mentioned by several authors, personality traits often underlie physiological or neuroendocrine correlates (Koolhaas et al., 1999; Van Riel et al., 2002; Carere et al., 2003; Feldker et al., 2003; Sluyter et al., 2003; Veenema et al., 2003; Øverli et al., 2006). This intrinsic characteristic of the individual should not be confused with non-repeatable variation in behaviours that may be determined by recent experience or environmental conditions (Dingemanse and de Goede, 2004).

Fasting has been extensively studied in several fish species since many species live through natural fasting periods and can survive for months without food (Love, 1980). This lack of food is a frequent occurrence for wild fish as a consequence of temporal and spatial food availability in the aquatic environment (Aranda et al., 2001). Numerous studies aimed to investigate metabolic consequences of fasting in fish (Black and Love, 1986; Gutiérrez et al., 1991; Blasco et al., 1992), while others focused on compensatory growth after fasting (Weatherley and Gill, 1987; Kim and Lovell, 1995; Paul et al., 1995; Hayward et al., 1997; Nicieza and Metcalfe, 1997; Jobling et al., 1999). Behaviour under fasting conditions has also been reported for larvae, juveniles, and adults of several species (Beukema, 1968; Laurence, 1972; Rice et al., 1987; Croy and Hughes, 1991) but to the best of our knowledge, there is no study testing the influence of fasting on individual specialization and the resulting group structure in self-feeding conditions for any species.

Thus, the aim of this study was to determine if HT behaviour is only the consequence of temporary and contextual feeding motivation. This question was approached by applying a period of fasting in order to induce similar negative specific growth among fish. If feeding motivation is directing HT behaviour acquisition and status, we hypothesise that rank-order (in relation with triggering-activity) of individuals should be modified after the fasting period. Further, the experiment was performed with two different size distribution groups, i.e. large and narrow coefficient of variation for weight, in order to test for results consistency in two usual situations met in aquaculture (graded vs. non-graded groups). Indeed, it has already been shown that social environment may be determined by factors such as size heterogeneity. In particular, it could affect feeding behaviour and 
swimming activity (Martins et al., 2005) or promote social hierarchy resulting in feed intake and specific growth rate that are proportional to fish size and weight (Alanärä and Brännäs, 1996 ).

\section{Materials and methods}

\subsection{Fish}

Sea bass juveniles used in this experiment were hatched and grown at the farm Aquanord SA (France). They were transferred to the experimental station of Ifremer L'Houmeau when they were 284 days old. After a two-week acclimation period, each fish was individually tagged by inserting a PIT-tag ${ }^{\circledR}$ horizontally just behind the head to prevent any change of position subsequent to implantation. Fish were weighed (to the nearest $\mathrm{mg}$ ) and measured for total length (to the nearest $\mathrm{mm}$ ).

\subsection{Experimental set-up}

The experiment was carried out in six 4001 tanks supplied with sand filtered seawater in a recirculated system (flow rate of $4 \mathrm{~m}^{3} \mathrm{~h}^{-1}$ in each tank, and $10 \%$ water renewal per day). Water temperature was maintained at $21.0 \pm 0.9^{\circ} \mathrm{C}$, oxygenation at $7.5 \pm 1.5 \mathrm{mg} \mathrm{l}^{-1}$, and salinity at $23.4 \pm 1.3 \%$. Tanks were surrounded by black curtains to reduce any disturbance to the fish, and individually lighted with a $120 \mathrm{~W}$ lamp located at $90 \mathrm{~cm}$ above the water surface. Light regime was 16:8 LD (light onset at 06:00 U.T. +1 ) with twilight transition periods of $30 \mathrm{~min}$. Fish were fed a commercial sea bass diet (Neo Start 3, France: 47\% crude protein, 18\% lipid according to the manufacturer, $3.2 \mathrm{~mm}$ ) provided with a self-feeder. The device to operate the feeder comprised a screened type sensor (a metal rod protected in a PVC cylinder surrounded by the tag detection antenna; Covès et al., 2006), and a control box. After each actuation, fish were rewarded with pellets, feed dispensers being regulated to distribute always the same quantity of food which corresponded, according to the fish biomass in tanks, to $0.8 \mathrm{~g} \mathrm{~kg}^{-1}$ of fish at the beginning of the experiment and $0.6 \mathrm{~g} \mathrm{~kg}^{-1}$ at the end. The reward level was a compromise between minimizing wastage, and optimizing feed allocation to the group. Such a set up allowed to monitor two variables of interest on a daily basis: the individual feed demand behaviour and the group (i.e. one group per tank) apparent feed consumption (uneaten pellets were counted). Apparent group feed consumption (food quantity dispensed minus waste counted on 
the bottom of the tank and in the sediment trap) was monitored daily. Triggering activity recordings were done continuously except before and during fish biometry sessions (no recordings during $48 \mathrm{~h}$ at each biometry session, triggers were taken out of the water). Fish were placed under self-feeding conditions at D1 (first day of the experiment), and food access was possible the whole day along (24 h) even during the cleaning of rearing units and the waste counting from 10:00 to 11:00 (U.T. + 1). The experiment lasted 145 days, and fish were weighed and measured at fortnight interval ( 9 measures in total). Fish were anesthetized with clove oil (40 $\left.\mathrm{mg}^{-1}\right)$ during handling.

\subsection{Experiment steps}

The first step consisted in a 25-day learning phase i.e. the time taken by the fish to learn actuation of the self-feeding trigger in each tank. At this stage, each tank hosted 100 fish of similar weight and size.

At D26, fish were size graded to create two different treatments: groups of fish of similar mean weight but with either a low or a high $\mathrm{CV}$ of weight $\left(\mathrm{CV}_{\mathrm{w}}\right)\left(\mathrm{T}_{\text {low }}: \mathrm{CV}_{\mathrm{w}} \sim 10 \%, 3\right.$ tanks of 60 fish each; $\mathrm{T}_{\text {high }} \mathrm{CV}_{\mathrm{w}} \sim 20 \%, 3$ tanks of 60 fish each). Their feed demand was recorded for 54 days (D27-D80). At D81, self-feeder systems were removed, and a 3-week fasting period applied (D81-102). At D103, self-feeder systems were set-up again, and a second feed demand period was recorded for 40 days (D103-142).

\subsection{Measured and calculated variables}

The variables chosen to evaluate biological performances and feeding behaviour within periods were the following:

- Body weight (BW in g), Total body length (BL in $\mathrm{cm}$ ), Specific growth rate: SGR (\% body weight per day $)=100($ Ln BWf - Ln BWi) / t, with BWf and BWi being the final and initial body weight $(\mathrm{g})$ respectively, and $\mathrm{t}$ the total number of days, Fulton index $(\mathrm{K}=$ $\left.100 * \mathrm{BW}^{*}\left(\mathrm{BL}^{3}\right)^{-1}\right)$ were measured on each fish.

-Feed demand (FD in g.kg $^{-1}$ of fish biomass), Food wastage (FW in g), and Feed efficiency ratio $($ FER $=$ Biomass gain $(\mathrm{g}) /$ total feed eaten $(\mathrm{g}))$ were measured at the tank level. 
- Daily feeding rhythms (measured at the tank level also) were calculated by taking into account the feeding demand per hour.

Fish individuals were characterized according to their triggering activity classifying them into 3 categories according to their proportional contribution to total number of trigger actuations within a group: high-triggering HT ( $>15 \%$ actuations), low-triggering LT $(<15 \%)$, and zero-triggering ZT $(<$ 2\%) individuals (based on Covès et al, 2006).

In order to evaluate physiological status i.e. to compare the physiological blood compositions before and after fasting and between $\mathrm{T}_{\text {high }}$ and $\mathrm{T}_{\text {low }}$ groups, 4 fish were randomly taken in each tank at D83 and D103 taking care however not to sample HT fish. Four more fish from each tank were similarly analysed at the end of the experiment (D145), including HT fish, ZT fish and random fish samplings. They were anesthetized, and a blood sample (c. $0.1 \mathrm{ml})$ was collected from caudal vessels with 1-ml preheparinized syringes. These samples were immediately analysed using an i-Stat ${ }^{\circledR}$ Portable Clinical Analyzer (Abbott; cartridges CG8+; Heska corporation, Fort Collins, CO, USA; (Harrenstien et al., 2005)). This apparatus analysed the 13 following variables:

- Potential of hydrogen $(\mathrm{pH})$

- Carbon dioxide partial pressure $\left(\mathrm{PCO}_{2}\right.$ in $\left.\mathrm{mm} \mathrm{Hg}\right)$

- Oxygen partial pressure $\left(\mathrm{PO}_{2}\right.$ in $\left.\mathrm{mm} \mathrm{Hg}\right)$

- $\quad$ Base excess (BE in $\left.\mathrm{mmol} \mathrm{L}^{-1}\right)$,

- $\quad$ Bicarbonate $\left(\mathrm{HCO}_{3}\right.$ in $\left.\mathrm{mmol} \mathrm{L}^{-1}\right)$

- Total carbon dioxide $\left(\mathrm{TCO}_{2}\right.$ in $\left.\mathrm{mmol} \mathrm{L}^{-1}\right)$

- Oxygen saturation ( $\mathrm{sO} 2$ in \%)

- Potassium ion $\left(\mathrm{K}^{+}\right.$in $\left.\mathrm{mmol} \mathrm{L}^{-1}\right)$

- $\quad$ Sodium ion $\left(\mathrm{Na}^{+}\right.$in $\left.\mathrm{mmol} \mathrm{L}^{-1}\right)$

- $\quad$ Ionized calcium (iCA in $\mathrm{mmol} \mathrm{L}^{-1}$ )

- Plasma glucose (Glu in $\left.\mathrm{mg} \mathrm{dL}^{-1}\right)$

- Hematocrit (Hct in \% PCV), and haemoglobin ( $\mathrm{Hb}$ in $\left.\mathrm{mmol} \mathrm{L}^{-1}\right)$ 
At D145, all fish were sacrificed and sexed. The gonads, liver and viscera of 4 fish randomly sampled in each tank were dissected, weighted and hepatosomatic (HS), viscerosomatic (VS) and gonadosomatic (GS) indexes were calculated as described by Storebakken et al. (1991).

\subsection{Data analysis}

All variables were compared using parametric analysis of variances (ANOVA) after verification of distribution normality and homoscedasticity (Dagnélie, 1975). When data did not fulfil these requirements, non parametric Kruskall-Wallis tests were used. Significant ANOVA were followed by a post-hoc multiple comparison test (Newman-Keuls), and Kruskall-Wallis test by a rankbased multiple comparisons (Zar, 1984).

Statistical analyses were conducted using Statistica 8 (Statsoft, USA), and for all tests, the significant threshold was $\mathrm{p}<0.05$.

Individual SGR values were compared using repeated measures analysis of variance with Treatment $\left(\mathrm{T}_{\text {low }}\right.$ vs. $\mathrm{T}_{\text {high }}$ groups) and Tank (random factor) nested to Treatment as between-subjects factors and Date (9 dates corresponding to 9 fish measurement dates) as within-subjects factor.

FD, FW, FER means were compared before (D27-D80) and after fasting (D102-D142) in each tank using a Student's t-test for independent samples. To test for treatment effect ( $\mathrm{T}_{\text {low }} v s . \mathrm{T}_{\text {high }}$ groups) on the same variables, means calculated from each triplicate were compared before fasting then after fasting using a Student's paired t-test.

Mann-Whitney tests were used to compare: i) the percentages of fish falling in each triggering category before and after fasting at D81 versus D103, and (ii) the latency time, i.e. the time taken by fish to perform the first self-feeder actuation between HT and first triggering fish at D103.

At last, some of the characteristics of the 3 fish triggering categories were compared: (i) their sex-ratio using a chi-square test, (ii) their SGR using a 2-way ANOVA with Treatment ( $\mathrm{T}_{\text {low }}$ vs. $\left.\mathrm{T}_{\text {high }}\right)$, fish triggering category (HT, LT and ZT), Sex as fixed factors and Tank as a random factor nested to treatment. Analyses were performed separately at D82, D102, D117, D130 and D144. 
Physiological blood parameters were compared using a Kruskal-wallis test with Treatment ( $\mathrm{T}_{\text {low }}$ vs. $\mathrm{T}_{\text {high }}$ groups) and Date (day 54, 82 and 144) as fixed factors.

GS, VS and HS recorded at the end of the experiment were compared using Kruskal-wallis test with Tank, Categories (triggering) and Sex as independent variables.

\section{Results}

\subsection{Growth and feed-demand behaviour at the group level}

Before fasting, all SGR were around $1.1 \%$ of body weight gain per day with low variation $(1.11 \pm 0.15 \%)$ between treatment or tank, while during fasting, they all reached negative values with a lower variation between treatment or tanks $(-0.50 \pm 0.08 \%)$ (Figure 1A). After fasting, SGR strongly increased reaching almost twice (x1.7 after a month) the values observed before fasting. At the end of the experiment, weight gain per day returned to the levels recorded before fasting $(1.23 \pm 0.13 \%)$. There was no SGR difference between $T_{\text {low }}$ and $T_{\text {high }}$ groups but significant tank(treatment) effect $\left(F_{4}\right.$, $\left.{ }_{278)}=30.2, \mathrm{P}<0.001\right)$. Newman-Keuls tests showed that this significant effect was due to tank 6 where SGR values were significantly lower to all other tanks at date $1(\mathrm{P}<0.001$ for each pairwise comparison), significantly higher to tanks 4 and 5 at date 3 and $5(\mathrm{P}<0.05$ for each pairwise comparison), significantly higher to all other tanks at date 8 ( $\mathrm{P}<0.001$ for each pairwise comparison). It was also due to tank 1 where SGR values were significantly lower to all other tanks at date 2 and 4 $(\mathrm{P}<0.05$ for each pairwise comparison), higher to all other tanks at Date 6 except for Tank 4 ( $\mathrm{P}<$ 0.001 for each pairwise comparison).

The theoretical growth curve calculated without fasting showed that the estimated final weight is almost identical to the observed data at the end of the experiment, i.e. 62 days after the end of the fasting period (Figure 1B). $\mathrm{CVw}$ (Figure 1B) remain stable in $\mathrm{T}_{\text {low }}$ and $\mathrm{T}_{\text {high }}$ groups. They tended to slightly decrease from the beginning to the end of the experiment in $\mathrm{T}_{\text {high }}$ groups (from $20.70 \pm 1.03 \%$ to $19.10 \pm 1.12 \%$ ) whereas they slightly increased in $\mathrm{T}_{\text {low }}$ groups (from $9.86 \pm 0.23 \%$ to $12.97 \pm$ $1.18 \%)$.

The whole experiment along, FD varied between 13.28 to $18.69 \mathrm{~g} \mathrm{~kg}^{-1}$ (min-max values), FER between 0.52 and 0.99 (Figure 1C) and FW remained very low varying between 0.0 and $5.1 \mathrm{~g}$ per day. 
There were no FD and FW significant differences but significant FER difference before and after fasting in tanks $1,4,5(\mathrm{df}=73, \mathrm{t}=2.9, \mathrm{P}<0.05 ; \mathrm{df}=76, \mathrm{t}=2.37, \mathrm{p}=0.02 ; \mathrm{df}=76, \mathrm{t}=2.07, \mathrm{P}=0.04$ respectively); no FD, FW and FER significant differences in tanks 2 and 6; FD and FER significant differences in tank $3(\mathrm{df}=78, \mathrm{t}=-4.3, \mathrm{P}<0.001 ; \mathrm{df}=76, \mathrm{t}=-4.1, \mathrm{p}<0.001$ respectively $)$.

No differences could be observed either between $\mathrm{T}_{\text {low }}$ and $\mathrm{T}_{\text {high }}$ groups nor before and after fasting for FD or FW $\left(15.85 \pm 1.46 \mathrm{~g} \mathrm{~kg}^{-1}, 0.60 \pm 0.50 \mathrm{~g}\right.$, before fasting and $16.40 \pm 2.80 \mathrm{~g} \mathrm{~kg}^{-1}, 0.29 \pm 0.26$ g, after fasting,), Tank 3 data being removed from the analysis because of the very high level of food wasted after the fasting period. The sole difference was recorded for FER that was significantly higher in $\mathrm{T}_{\text {low }}$ groups before fasting $(\mathrm{df}=41, \mathrm{t}=2.25, \mathrm{P}=0.03)$.

Feeding rhythms were similar before and after fasting with peaks of higher activity observed at 6:00, 10:00, 11:00 and 12:00 (Figure 2).

\subsection{Individual feed demand behaviour}

Triggering activity categories were very similar before and after fasting (Figure 3). Most of the fish almost never (i.e. $0-1 \%$ of triggering activity) actuated the trigger $(65.6 \pm 7.4 \%$ before fasting and $67.8 \pm 6.1 \%$ after fasting). Another important category was fish having a triggering activity of 2 to 5\%: $29.1 \pm 8.8 \%$ of the fish before fasting and $27.3 \pm 5.9$ after fasting for this class. The most important triggering activity was therefore performed by 1 to 10 individuals per tank before fasting and 1 to 6 individuals per tank after fasting (Figure 4). The only difference recorded before and after fasting was the increase of the higher triggering activity performed by a single fish (Figure 3).

HT fish remained the same before and after fasting (Figure 4). In tanks 1 and 4, this was verified for a single fish per tank that performed a very high level of activity that doubled after the fasting period (Figure 4): $28.4 \pm 19.5 \%$ and $33.2 \pm 20.4 \%$ of the triggering activity of their respective tank. In other tanks, similar results were observed but for a group of two or 4 fish. In tank 6, there was no real HT but the higher ranked fish before fasting slightly increased its activity after fasting while the fish that was in second position strongly increased its activity. 
In tank 5 , two fish performed similar activity before and after fasting. In tank 2 , two fish performed the highest triggering activity but their ranks were reversed before and after fasting. In tank 3, 4 fish performed similar triggering activity before fasting, but this activity decreased for two of them after fasting while it increased for the other two.

The latency time to the first triggering activity after fasting (22.2 $\pm 13.6 \mathrm{~min})$ was not different from the HT fish latency time $(\mathrm{Z}=-1.28, \mathrm{P}=0.20)$. First trigger actuations were performed by HT fish in tanks 2 and 4 and by LT fish in tanks 1, 3, 5, 6 (Figure 5).

\subsection{Individual characteristics}

Sex ratio was similar in all tanks $(1.49 \pm 0.21 \%$ of females $)$ and not correlated with triggering activity. For SGR, no effect of Treatment, Triggering category or Sex could be observed at any dates but Tank(Treatment) effect was significant $\left(\mathrm{F}_{(4,334)}=13.2, \mathrm{P}<0.01 ; \mathrm{F}_{(4,334)}=8.3, \mathrm{P}<0.01 ; \mathrm{F}_{(4,334)}=\right.$ 9.3, $\mathrm{P}<0.01 ; \mathrm{F}_{(4,334)}=5.3, \mathrm{P}<0.01 ; \mathrm{F}_{(4,334)}=30.0, \mathrm{P}<0.01$ respectively from $\mathrm{D} 82$ to $\left.\mathrm{D} 144\right)$.

Neither Tank nor Treatment ( $\mathrm{T}_{\text {low }} v s . \mathrm{T}_{\text {high }}$ groups) effects were observed for any physiological variables but they differed according to Date (Table 1). Numerous variables significantly decreased after the fasting period i.e. $\mathrm{PCO}_{2}, \mathrm{HCO}_{3}, \mathrm{TCO}_{2}$, Glucose, $\mathrm{Hct}$ and $\mathrm{Hb}$. These values increased again at the end of the experiment reaching similar values as the ones recorded before fasting or even higher values i.e. $\mathrm{PCO}_{2}, \mathrm{Na}, \mathrm{K}$ and Glucose. Only $\mathrm{sO}_{2}$ was significantly lower after fasting, and at the end of the experiment

No Tank, Category nor Sex differences were recorded for any physiological variables at the end of the experiment. The only difference concerned GS that was higher in females $(0.20 \pm 0.05 \%)$ than in males $\left(0.05 \pm 0.01, \mathrm{H}_{(1,23)}=16.5, \mathrm{P}<0.0001\right)$.

\section{Discussion}

This work aimed to determine if HT behaviour is only the consequence of temporary and contextual feeding motivation. Therefore, a period of fasting was applied in order to induce similar negative SGR values among two groups of fish (differing by their size-distribution). Consistency in 
HT behaviour was evaluated between periods and groups in order to test the hypothesis of feeding motivation governing the observed triggering responses.

This study showed that feed demand behaviour was not strongly modified by a three-week fasting period. At the individual level, it was confirmed that only a few individuals were responsible for most of the triggering activity. The HT status could neither be explained by an initial lower SGR nor by a sex effect, nor by any of the measured physiological blood parameters. Individuals triggering activity that took place in each tank was consistent within individuals across time and in two contexts (two different size distribution). This could be related to personality and/or metabolic traits but further research is needed to confirm this assumption.

\subsection{Growth, feed-demand behaviour and physiology at the group level}

Growth performances were similar in low and high $\mathrm{CV}_{\mathrm{w}}$ groups. The fasting period induced similar negative SGR values in all individuals that were associated to plasma glucose decrease in accordance with levels given by previous study on sea bass (Echevarria et al., 1997), and to hematocrit decrease, which has been already described in other fish species (Muller et al., 1983; Boismenu et al., 1992; Gillis and Ballantyne, 1996; Neubert et al., 1999).

A parallel decrease of $\mathrm{PCO}_{2}, \mathrm{HCO}_{3}$ and $\mathrm{TCO}_{2}$ was also observed that could be linked to the fact that fish deprived of food reduce their oxygen consumption (and therefore their $\mathrm{CO}_{2}$ production) by decreasing their energy expenditure in an attempt to conserve body energy reserves (Cook et al., 2000; O'Connor et al., 2000; Rios et al., 2002).

During the four weeks following the fasting period, fish exhibited accelerated growth. They grew indeed very fast, and at the end of the experiment they achieved the same body mass than fish that would have been continuously fed, indicating a complete compensation (Kim and Lovell, 1995; Nicieza and Metcalfe, 1997; Jobling et al., 1999). Previous studies already showed complete compensatory growth in Atlantic cod Gadus morhua after deprivation for 3 weeks (Jobling and Baardvick, 1994). In the present study, this growth acceleration was not associated with hyperphagia (i.e. feed demand did not strongly increase after the fasting period), but with food conversion 
efficiency improvement, which is one of the major mechanisms causing compensatory growth during the period of re-feeding (Dobson and Holmes, 1984; Russell and Wootton, 1992; Qian et al., 2000).

Feeding rhythm was neither influenced by size distribution (low and high $\mathrm{CVw}$ groups) nor by fasting and 4 main peaks were recorded at 6:00, 10:00, 11:00 and 12:00, which are close to rhythms described previously under similar conditions (Millot et al., 2009).

\subsection{Individual feed-demand behaviour}

The self-feeder triggering activity was very similar before and after fasting. This study confirms that, in a group of 50-140g sea bass (60 individuals), a few individuals only are responsible of more than a third of the triggering activity, the rest of the population being composed here, of around $66 \%$ of ZT fish and $28 \%$ of fish performing $2-5 \%$ of triggering. An interesting result is that fasting induced higher activity only in fish that had already acquired the HT status before fasting.

The most important result of this study came up when comparing the triggering activity of each tagged fish before and after fasting: feeding motivation was not revealed to be the major factor explaining the different levels of activity. Indeed, because all fish were similarly fasted, it was expected according to the feeding motivation hypothesis (Millot et al. 2008), that several fish should have acquired HT status after the fasting period, but this was not the case because HT fish maintained their status before and after fasting. In some cases, a single fish could even perform a third of the total triggering activity that represented 3-4 times more than the most active LT fish. In other cases, the same group of 2 or 4 fish was found before and after fasting but with different rankings (according to the triggering activity level). This social structure seemed therefore to remain very stable, and here, a small number of fish ( 1 to 4 ) kept a high level of triggering activity during 96 days including a period of 55 days before fasting and a period of 41 days after fasting. Millot et al. (2008) showed that a HT fish could keep its status during approximately $63 \pm 16$ days on average (12-186, min-max) and when loosing it, a new fish previously identified as a LT fish, was replacing it. The present work showed that fish rankings according to their triggering activity levels in each tank should also be considered. 
Indeed, we hypothesize that not all LT fish have the same potential to become HT fish, and that only those that are able to maintain themselves at a high ranking level can do it. In the present work, fish that lost their first position in term of activity were still among the more active individuals. Rankings reversal could indicate a competition situation among the more active fish that would explain the HT status changes described previously (Millot et al, 2008), and the fact that HT fish removed from tanks are replaced by the same number of new HT fish (Di-Poï et al., 2008). Millot et al. (2008) already mentioned the hypothesis of HT fish dominance on other fish categories. Dominance does not necessarily imply aggression among fish e.g. exploitation or scramble competitions (Ward et al., 2006). The observed stability of the social structure could be explained by social interactions that are known to influence animal activities resulting in efficient adaptative behaviour (Galef, 1995; Galef Jr et al., 1996).

The latency time to actuate the trigger after the fasting period was very short in all tanks (11 to 43 min) while it was $17.7 \pm 2.7$ hours during the learning phase. This confirms that trigger actuation relies upon cognition, which includes memory formation and executive functions related to information processing such as learning and problem solving functions (Brown et al., 2006). Even though the very first actuations were performed in 4 of the 6 tanks by LT fish, their latency time was not significantly different from HT ones. It is also notable that the feeding rhythm was established again immediately without food wastage increase in 5 tanks out of 6 .

This suggested that trigger actuation among sea bass populations can not be fully explained by feeding motivation. One hypothesis is that trigger actuation could be classified in "activity", which is one of the 5 personality traits category described by Réale et al. (2007) because, in all cases some individuals consistently differed in activity levels (HT vs LT vs ZT fish). As already mentioned above, further research would be useful to determine the frontier between LT and HT fish i.e. to check if all fish belonging to the LT fish category have really the same potential to become HT fish. Some authors already pointed out that more studies were also needed to discern generalities on the breadth of behavioural syndromes (i.e. on the range of behavioural correlations, Sih et al., 2004). The personality 
traits need reflecting consistency in behaviour between individual across two or more situations (Sih et al., 2004), which was the case here, across two situations (before and after fasting; low and high $\mathrm{CV}_{\mathrm{w}}$ groups), and for the 96 days that lasted the experiment.

There were neither blood parameters responses nor growth performances (except a higher body weight in LT fish compared to ZT fish) nor sex differences between HT, LT and ZT fish. However, we did not investigate metabolic traits that could explain the HT status acquisition. Indeed, in our study the HT increased their activity after fasting and their status lasted 96 days while Millot et al (2008), when performing a long-term study on sea bass under self-feeding conditions, showed that the HT were keeping their status during 60 days on average. This longer period could be explained by a metabolic trait that could be reinforced by the fasting period. It would have been interesting to compare HT physiological parameters between the beginning and the end of the experiment to investigate more accurately the metabolic trait explanation but the blood sampling itself can induce stress which could have changed the triggering status (Millot, 2008; Millot and Bégout, 2009).

Nevertheless, the plasticity of the behavioural response in relation to environment variation is not a sticking point with the personality traits definition since some authors stated that personality and plasticity could be considered as complementary aspects of the individual phenotype (Dingemanse et al., 2009). Furthermore, personality can underlie physiological or neuroendocrine correlates (Koolhaas et al. 1999; van Riel et al. 2002; Carere et al. 2003; Feldker et al. 2003; Sluyter et al. 2003; Veenema et al. 2003; Overli et al. 2006). Specifically in sea bass, Di-Poï et al (2007) already showed that HT fish had lower serotonergic turnover than LT and ZT fish and hypothesized it could be linked to a bold personality trait.

In conclusion, this study brought forward evidence to demonstrate that in sea bass: (i) high-triggering status is not regulated by a negative growth, (ii) feeding motivation seems not to be the sole factor that determines individual activity level, and (iii) triggering activity could be associated to personality traits but our protocol did not allow to reject the hypothesis stating that there were no difference in feeding motivation before and after fasting and therefore to directly assess personality. Further 
research is needed to better understand the HT status acquisition. In particular, new questions arose about the low-triggering category, which could be probably better described i.e. subcategories should be identified. We suggest investigating HT personality traits in dedicated experiments since the triggering activity could be correlated to other personality traits as described in behavioural syndromes (Koolhaas et al., 1999; Réale et al., 2000). At last, experiments in calorimetric chambers could be useful to determine the potential importance of metabolic traits associated with HT behaviour status.

\section{Acknowledgments}

We are grateful to Aquanord company for providing animals. Many thanks to Jean-Luc Durand from University of Paris 13 for statistical help. We also thank some students from Ifremer L'Houmeau for precious technical help during this experiment. This study was conducted under the approval of the Animal Care Committee of France under the official licence of M.L. Bégout (17-010).

\section{References}

Alanärä, A., Brännäs, E., 1993. A test of individual feeding activity and food size preference in rainbow trout using demand feeders. Aquac. Int. 1, 47-54.

Alanärä, A., Brännäs, E., 1996 Dominance in demand-feeding behaviour in Arctic charr and rainbow trout: the effect of stocking density. J. Fish Biol. 48 242-254.

Alanärä, A., Winberg, S., Brännäs, E., Kiessling, A., Höglund, E., Elofsson, U., 1998. Feeding behaviour, brain serotonergic activity levels, and energy reserves of Arctic char (Salvelinus alpinus) within a dominance hierarchy. Can. J. Zool. 76, 212-220.

Aranda, A., Sánchez-Vázquez, F.J., Madrid, J.A., 2001. Effect of short-term fasting on macronutrient self-selection in sea bass. Physiol. Behav. 73, 105-109.

Beukema, J.J., 1968. Predation by the three-spined stickleback Gasterosteus aculeatus L.: the influence of hunger and experience. In: Baerends, G.P., Carpenter, C.R., Grasse, P.P., Van Iersel, J.J.A., Thorpe, W.H., Fabricius, E., Hediger, H., Koehler, O., Tinbergen, N. (Eds.), Behaviour. E.J. Brill, Leiden, pp. $1-126$.

Black, D., Love, R.M., 1986. The sequential mobilisation and restoration of energy reserves in tissues of Atlantic cod during starvation and refeeding. J. Comp. Physiol. 156, 469-479. 
Blasco, J., Fernandez, J., Gutiérrez, J., 1992. Fasting and refeeding in carp, Cyprinus carpio L.: the mobilization of reserves and plasma metabolite and hormone variations. J. Comp. Physiol. 162, 346359.

Boismenu, C., Gauthier, G., Larochelle, J., 1992. Physiology of prolonged fasting in greater snow geese (Chen caerulescens atlantica). Auk 109, 511-521.

Boujard, T., Jourdan, M., Kentouri, M., Divanach, P., 1996. Diel feeding activity and the effect of timerestricted self-feeding on growth and feed conversion in European sea bass. Aquaculture 139, 117 127.

Boujard, T., Leatherland, J.F., 1992. Demand-feeding behavior and diel pattern of feeding activity in Oncorhynchus mykiss held under different photoperiod regimes. J. Fish Biol. 40, 535-544.

Brännäs, E., Alanärä, A., 1993. Monitoring the feeding activity of individual fish with a demand feeding system. J. Fish Biol. 42, 209-215.

Brown, C., Laland, K.N., Krause, J.D., 2006. Fish cognition and behavior / edited by Culum Brown, Kevin Laland, Jens Krause. Blackwell, Oxford, England :.

Carere, C., Groothuis, T.G.G., Möstl, E., Daan, S., Koolhaas, J.M., 2003. Fecal corticosteroids in a territorial bird selected for different personalities: daily rhythm and the response to social stress. Horm. Behav. 43, 540-548.

Coleman, K., Wilson, D.S., 1998. Shyness and boldness in pumpkinseed sunfish: individual differences are context-specific. Anim. Behav. 56, 927-936.

Cook, J.T., Sutterlin, A.M., McNiven, M.A., 2000. Effect of food deprivation on oxygen consumption and body composition of growth-enhanced transgenic Atlantic salmon (Salmo salar). Aquaculture $188,47-63$.

Covès, D., Beauchaud, M., Attia, J., Dutto, G., Bouchut, C., Bégout, M.L., 2006. Long-term monitoring of individual fish triggering activity on a self-feeding system: An example using European sea bass (Dicentrarchus labrax). Aquaculture 253, 385-392.

Croy, M.I., Hughes, R.N., 1991. The influence of hunger on feeding behaviour and on the acquisition of learned foraging skills by the fifteen-spined stickleback, Spinachia spinachia L. Anim. Behav. 41, $161-170$.

Dagnélie, P., 1975. Théorie et méthodes statistiques. Applications agronomiques. Vol. II. Les méthodes de l'inférence statistique. Les Presses agronomiques, Gembloux, 463p.

Di-Poï, C., Attia, J., Bouchut, C., Dutto, G., Covès, D., Beauchaud, M., 2007. Behavioral and neurophysiological responses of European sea bass groups reared under food constraint. Physiol. Behav. 90, 559-566.

Di-Poï, C., Beauchaud, M., Bouchut, C., Dutto, G., Covès, D., Attia, J., 2008. Effects of high food demand fish removal in groups of juvenile sea bass (Dicentrarchus labrax). Can. J. Zool. 86, 10151023. 
Dingemanse, N.J., de Goede, P., 2004. The relation between dominance and exploratory behavior is context-dependent in wild great tits. Behav. Ecol. 16, 1023-1030.

Dingemanse, N.J., Kazem, A.J.N., Réale, D., Wright, J., 2009. Behavioural reaction norms: animal personality meets individual plasticity. Trends Ecol. Evol. 25 81-89.

Dobson, S.H., Holmes, R.M., 1984. Compensatory growth in the rainbow trout, Salmo gairdneri Richardson. J. Fish Biol. 25, 649- 656.

Echevarria, G., Martinez-Bebia, M., Zamora, S., 1997. Evolution of Biometric Indices and Plasma Metabolites During Prolonged Starvation in European Sea Bass (Dicentrarchus labrax, L.). Comp. Biochem. Physiol. 118A, 111-123.

Feldker, D.E.M., Datson, N.A., Veenema, A.H., Meulmeester, E., De Kloet, E.R., Vreugdenhil, E., 2003. Serial analysis of gene expression predicts structural differences in hippocampus of long attack latency and short attack latency mice. Eur. J. Neurosci. 17, 379-387.

Galef, B.G., 1995. Why behaviour patterns that animals learn socially are locally adaptive. Anim. Behav. 49, 1325-1334.

Galef Jr, B.G., Cecilia, M.H., Bennett, G.G., Jr, 1996. Introduction, Social Learning in Animals, Academic Press, San Diego, pp. 3-15.

Gillis, T.E., Ballantyne, J.S., 1996. The effects of starvation on plasma free amino acid and glucose concentrations in lake sturgeon. J. Fish Biol. 49, 1306-1316.

Godin, J.-G.J., Dugatkin, L.A., 1996. Female mating preferences for bold males in the guppy, Poecilia reticulata. Proc. Natl. Acad. Sci. U. S. A., 10262-10267.

Gutiérrez, J., Pérez, J., Navarro, I., Zanuy, S., Carrillo, M., 1991. Changes in plasma glucagon and insulin associated with fasting in sea bass (Dicentrarchus labrax) Comp. Biochem. Physiol. 118A, 111-123.

Harrenstien, L.A., Tornquist, S.J., Miller-Morgan, T.J., Fodness, B.G., Clifford, K.E., 2005. Evaluation of a point-of-care blood analyzer and determination of reference ranges for blood parameters in rockfish J. Am. Vet. Med. Assoc. 226, 255-265.

Hayward, R.S., Noltie, D.B., Wang, N., 1997. Use of compensatory growth to double hybrid sunfish growth rates. Trans. Am. Fish. Soc. 126, 316- 322.

Heilman, M.J., Spieler, R.E., 1999. The daily feeding rhythm to demand feeders and the effects of timed meal-feeding on the growth of juvenile Florida pompano, Trachinotus carolinus. Aquaculture 180, 5364.

Jobling, M., Baardvick, B.M., 1994. The influence of environmental manipulations on inter- and intrainidivdual variation in food acquisition and growth performance of Arctic charr, Salvelinus alpinus. J. Fish Biol. 44, 1069-1087.

Jobling, M., Koskela, J., Winberg, S., 1999. Feeding and growth of whitefish fed restricted and abundant rations: influences on growth heterogeneity and brain serotonergitic activity. J. Fish Biol. 54 437-449. 
Kim, M.K., Lovell, R.T., 1995. Effect of restricted feeding regimens on compensatory weight gain and body tissue changes in channel catfish Ictalurus punctatus in ponds. Aquaculture 135, 285-293.

Koolhaas, J.M., Korte, S.M., De Boer, S.F., Van Der Vegt, B.J., Van Reenen, C.G., Hopster, H., De Jong, I.C., Ruis, M.A.W., Blokhuis, H.J., 1999. Coping styles in animals: current status in behavior and stress-physiology. Neurosci. Biobehav. Rev. 23, 925-935.

Laurence, G.C., 1972. Comparative swimming abilities of fed and starved larval largemouth bass (Micropterus salmoides). J. Fish Biol. 4, 73-78.

Lima, S.L., Anders Pape Møller, M.M., Peter, J.B.S., 1998. Stress and Decision Making under the Risk of Predation: Recent Developments from Behavioral, Reproductive, and Ecological Perspectives, Adv. Study Behav., Academic Press, pp. 215-290.

Love, R.M., 1980. The chemical biology of fishes. American Press: London, New-York.

Martins, C.I.M., Aanyu, M., Schrama, J.W., Verreth, J.A.J., 2005. Size distribution in african catfish (Clarias gariepinus) affects feeding behaviour but not growth. Aquaculture 250, 300-307.

Millot, S., 2008. DOMESTICATION, SELECTION ET COMPORTEMENT DU BAR. Variabilité des aptitudes comportementales et de la tolérance au stress de groupes génétiquement distincts de bar, Dicentrarchus labrax. Thèse doc., La Rochelle., 188 pp.

Millot, S., Bégout, M.-L., 2009. Individual fish rhythm directs group feeding: a case study with sea bass juveniles (Dicentrarchus labrax) under self-demand feeding conditions. Aquat. Living Resour. 22, 363-370.

Millot, S., Bégout, M.-L., Chatain, B., 2009. Exploration behaviour and flight response toward a stimulus in three sea bass strains (Dicentrarchus labrax L.). Appl. Anim. Behav. 119, 108-114.

Millot, S., Bégout, M.-L., Person-Le Ruyet, J., Breuil, G., Di-Poï, C., Fievet, J., Pineau, P., Roué, M., Sévère, A., 2008. Feed demand behavior in sea bass juveniles: effects on individual specific growth rate variation and health (inter-individual and intergroup variation). Aquaculture 274, 87-95.

Muller, M.J., Paschen, U., Seits, H.J., 1983. Glucose production measured by tracer and balance data in conscious miniature pig. Am. J. Physiol. 244, E236-E244.

Neubert, E., Scholze, C., Kratzsch, J., Gurtler, H., 1999. Plasma levels of catecholamines and lipolysis during starvation in growing pigs. J. Vet. Med. Assoc. 46, 247-253.

Nicieza, A.G., Metcalfe, N.B., 1997. Growth compensation in juvenile Atlantic salmon: responses to depressed temperature and food availability. Ecology 78, 2385- 2400.

O'Connor, K.I., Taylor, A.C., Metcalfe, N.B., 2000. The stability of standard metabolic rate during a period of food deprivation in juvenile Atlantic salmon. J. Fish Biol. 57, 41-51.

Øverli, Ø., Sørensen, C., Nilsson, G.E., 2006. Behavioral indicators of stress-coping style in rainbow trout: Do males and females react differently to novelty? Physiol. Behav. 87, 506-512.

Paspatis, M., Boujard, T., 1996. A comparative study of automatic feeding and self-feeding in juvenile Atlantic salmon (Salmo salar) fed diets of different energy levels. Aquaculture 145, 245-257. 
Paul, A.J., Paul, J.M., Smith, R.L., 1995. Compensatory growth in Alaska yellowfin sole, Pleuronectes asper, following food deprivation. J. Fish Biol. 46, 442- 448.

Qian, X., Cui, Y., Xiong, B., Yang, Y., 2000. Compensatory growth, feed utilization and activity in gibel carp, following feed deprivation. J. Fish Biol. 56, 228-232.

Réale, D., Gallant, B.Y., Leblanc, M., Festa-Bianchet, M., 2000. Consistency of temperament in bighorn ewes and correlates with behavior and life history. Anim. Behav. 60, 589-597.

Réale, D., Reader, S.M., Sol, D., McDougall, P.T., Dingemanse, N.J., 2007. Integrating animal temperament within ecology and evolution. Biol. Rev. Camb. Philos. Soc. 82, 291-318.

Rice, J.A., Crowder, L.B., Binkowski, F.P., 1987. Evaluating potential sources of mortality for larval bloater (Coregonus hoyi): starvation and vulnerability to predation. Can. J. Fish. Aquat. Sci. 44, 467472.

Rios, F.S., Kalinin, A.L., Rantin, F.T., 2002. The effects of long-term food deprivation on respiration and haematology of the neotropical fish Hoplias malabaricus. J. Fish Biol. 61, 85-95.

Rubio, V.C., Vivas, M., Sanchez-Mut, A., Sanchez-Vazquez, F.J., Coves, D., Dutto, G., Madrid, J.A., 2004. Self-feeding of European sea bass (Dicentrarchus labrax, L.) under laboratory and farming conditions using a string sensor. Aquaculture 233, 393-403.

Russell, N.R., Wootton, R.J., 1992. Appetite and growth compensation in the European minnow, Phoxinus phoxinus (Cyprinidae) following short periods of food restriction. Environ. Biol. Fish. 34, 277- 285.

Sánchez-Vázquez, F.J., Azzaydi, M., Martinez, F.J., Zamora, S., Madrid, J.A., 1998. Annual rhythms of demand-feeding activity in sea bass: evidence of a seasonal phase inversion of the diel feeding pattern. Chronobiology International 15, 607-622. .

Sánchez-Vázquez, F.J., Madrid, J.A., Zamora, S., 1995. Circadian rhythms of feeding activity in sea bass, Dicentrarchus labrax L.: dual phasing capacity of diel demand-feeding pattern. J. Biol. Rhythms $10,256-266$.

Sánchez-Vázquez, F.J., Yamamoto, T., Akiyama, T., Madrid, J.A., Tabata, M., 1999. Macronutrient Self-Selection Through Demand-Feeders in Rainbow Trout. Physiol. Behav. 66, 45-51.

Sih, A., Bell, A., Chadwick Johnson, J., 2004. Behavioral syndromes: an ecological and evolutionary overview. Trends Ecol. Evol. 19, 372-378.

Sluyter, F., Arseneault, L., Moffitt, T.E., Veenema, A.H., de Boer, S., Koolhaas, J.M., 2003. Toward an animal model for antisocial behavior: parallels between mice and humans. Behav. Genet. 33, , 563574.

Sneddon, L.U., 2003. The bold and the shy: individual differences in rainbow trout. J. Fish Biol. 62 971975.

Storebakken, T., Hung, S.S.O., Calvert, C.C., Plisetskaya, E.M., ., 1991. Nutrient partitioning in rainbow trout at different feeding rates. . Aquaculture 96, 191-203. 
Van Riel, E., Meijer, O.C., Veenema, A.H., Joels, M., 2002. Hippocampal serotonin responses in short and long attack latency mice. J. Neuroendocrinol. 14, 234-239.

Veenema, A.H., Meijer, O.C., de Kloet, E.R., Koolhaas, J.M., 2003. Genetic selection for coping style predicts stressor susceptibility. J. Neuroendocrinol. 15, 256-267.

Ward, A.J.W., Webster, M.M., Hart, P.J.B., 2006. Intraspecific food competition in fishes. Fish Fish. (Oxf.) 7, 231-261.

Weatherley, A.H., Gill, H.S., 1987. The Biology of Fish Growth. Academic Press, London. 443 pp.

Werner, E.E., Anholt, B.R., 1993. Ecological consequences of the trade-off between growth and mortality rates mediated by foraging activity. Am. Nat. 142 242-272.

Winberg, S., Nilsson, G.r.E., 1993. Roles of brain monoamine neurotransmitters in agonistic behaviour and stress reactions, with particular reference to fish. Comparative Biochemistry and Physiology Part C: Pharmacology, Toxicology and Endocrinology 106, 597-614.

Yamamoto, T., Shima, T., Furuita, H., Shiraishi, M., Sánchez-Vázquez, F.J., Tabata, M., 2000a. Selfselection of diets with different amino acid profiles by rainbow trout (Oncorhynchus mykiss). Aquaculture 187, 375-386.

Yamamoto, T., Shima, T., Unuma, T., Shiraishi, M., Akiyama, T., Tabata, M., 2000b. Voluntary intake of diets with varying digestible energy contents and energy sources, by juvenile rainbow trout Oncorhynchus mykiss, using self-feeders. Fish. Sci. (Tokyo) 66, 528- 534.

Zar, J.H., 1984. Biostatistical analysis, 2nd edn. Prentice Hall, Englewood Cliffs. 


\section{Figures and tables}
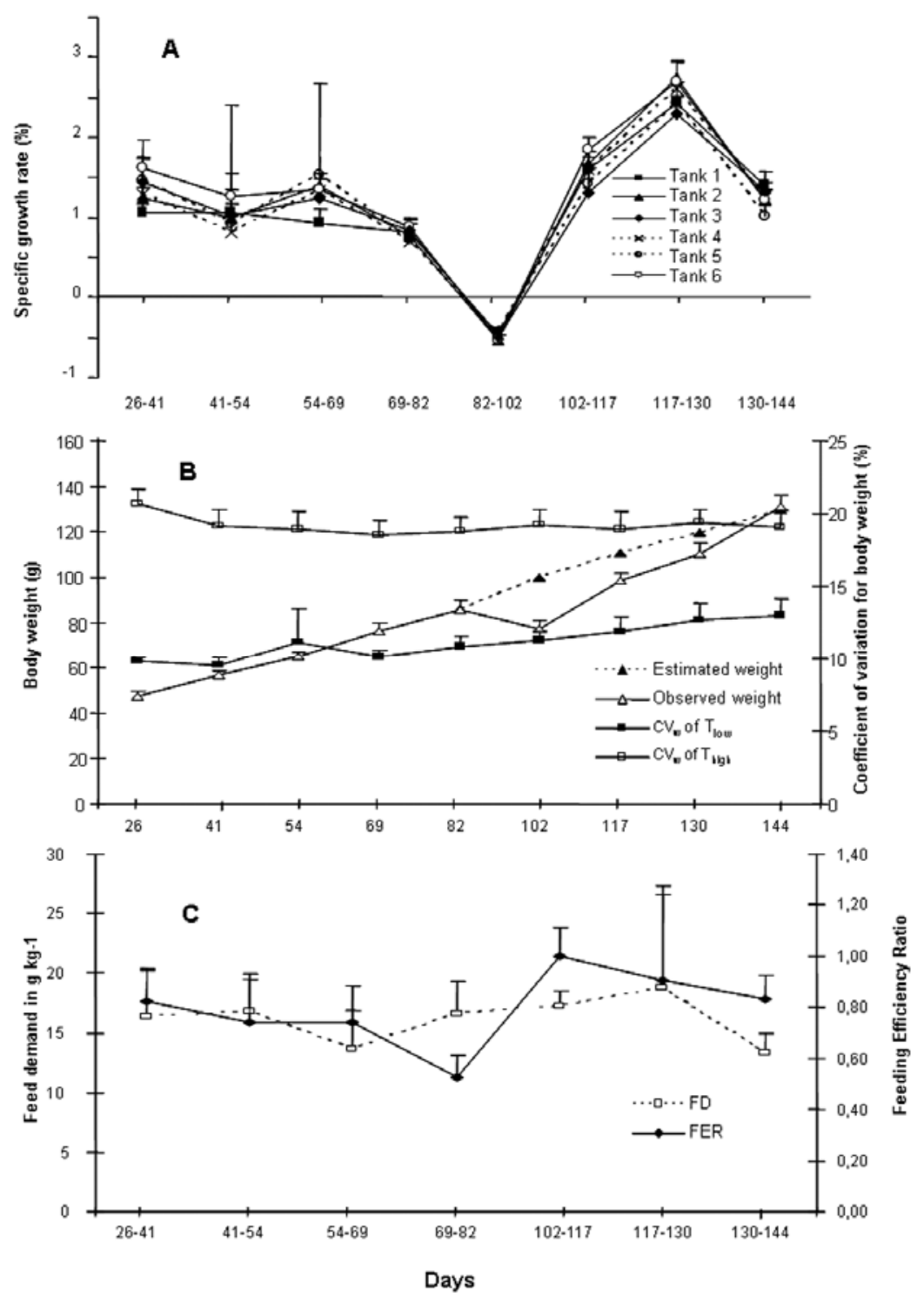

Figure 1. Growth performances before and after fasting period. Fish were fasted between day 81-102.

A. Mean \pm standard deviation of Specific Growth Rates in $\mathrm{T}_{\text {low }}(\mathrm{CV} \sim 10 \%$ : low $\mathrm{CV}$ of weight) and $\mathrm{T}_{\text {high }}\left(\mathrm{CV} \sim 20 \%\right.$ : high $\mathrm{CV}$ of weight). Tanks 1, 2, 3 are $\mathrm{T}_{\text {low }}$ groups; tanks 4, 5, 6 are $\mathrm{T}_{\text {high }}$ groups.

B. Mean \pm standard deviation of observed (white dots) and theoretical (black dots) body weight evolution within age (all tanks data pooled). The theoretical growth was an extrapolation of the growth fish would have stand without fasting (between day 82 and 102). This curve is based on the regression $(y=0,6941 x-27693)$ calculated from day 26 to day 82 with a coefficient of determination $r 2=0.998$. Mean \pm standard deviation of coefficients of variation for weight $(\mathrm{CVw})$ in Tlow and Thigh groups. C. Mean \pm standard deviation of Feeding Efficiency Ratio (FCR) and Feeding demand (FD). 


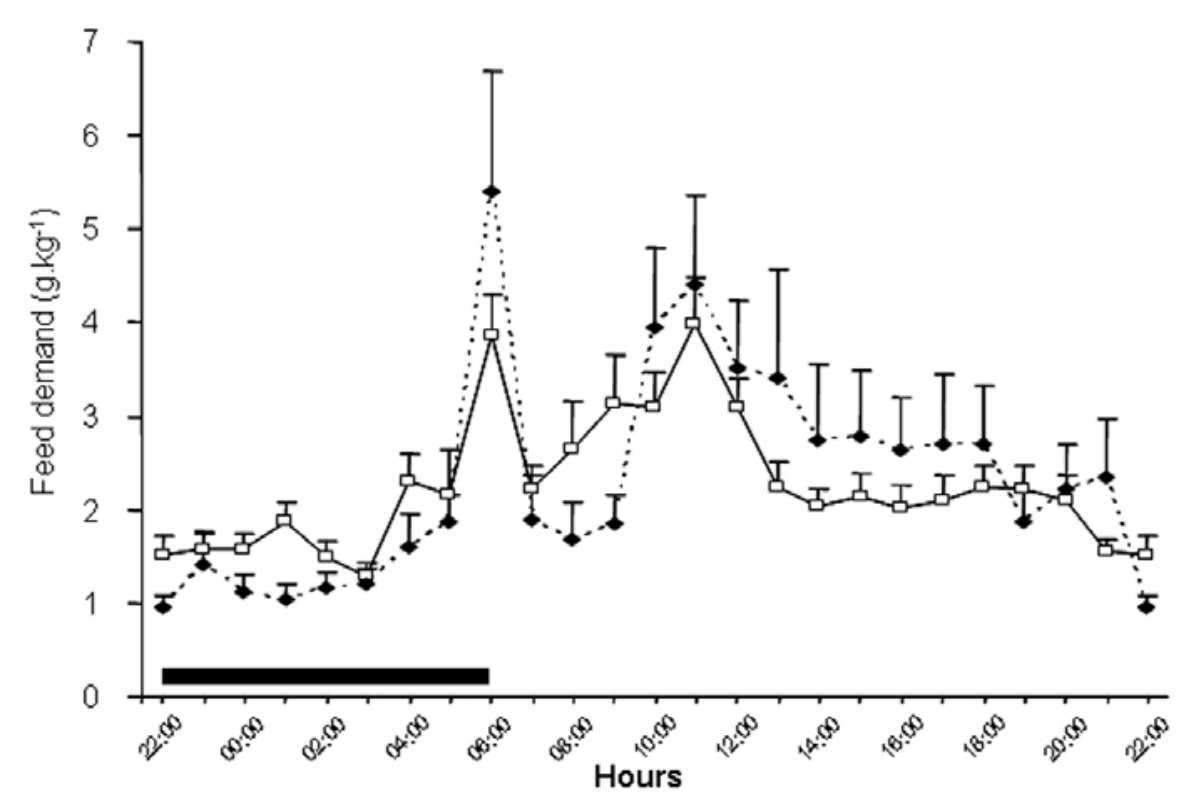

Figure 2. Mean \pm standard deviation of feeding rhythm before (white dots) and after (black dots) fasting period. The black mark on the X-axis represents the night period.
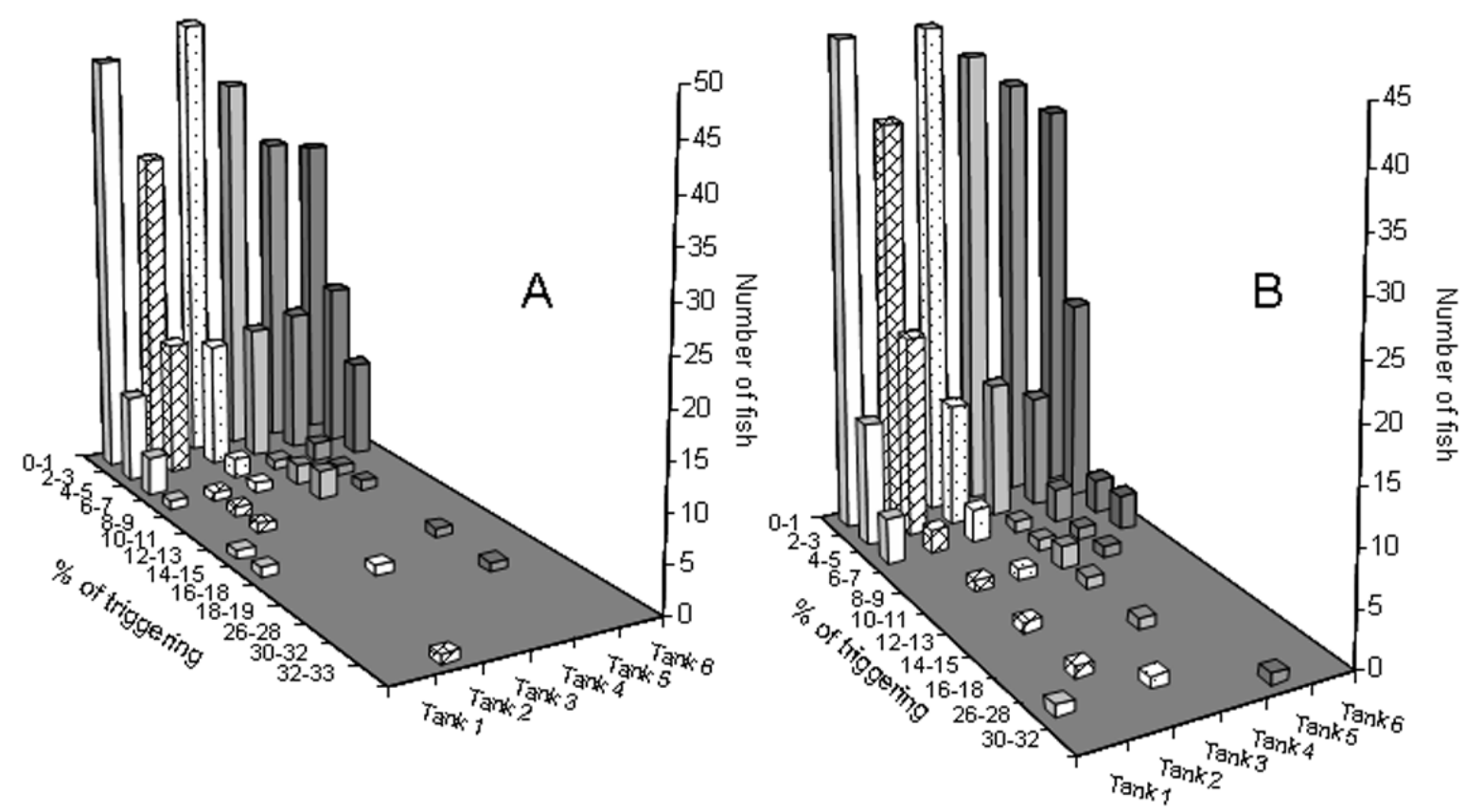

Figure 3. Number of fish in different triggering classes (expressed in \%) in $\mathrm{T}_{\text {low }}(\mathrm{CV} \sim 10 \%:$ low $\mathrm{CV}$ of weight) (Tanks 1, 2, 3) and $\mathrm{T}_{\text {high }}(\mathrm{CV} \sim 20 \%$ : high CV of weight) (Tanks 4, 5, 6) groups.

A: before fasting (Day 27-80), B: after fasting (Day 103-142). Fish were fasted during the 81-102 day period. 

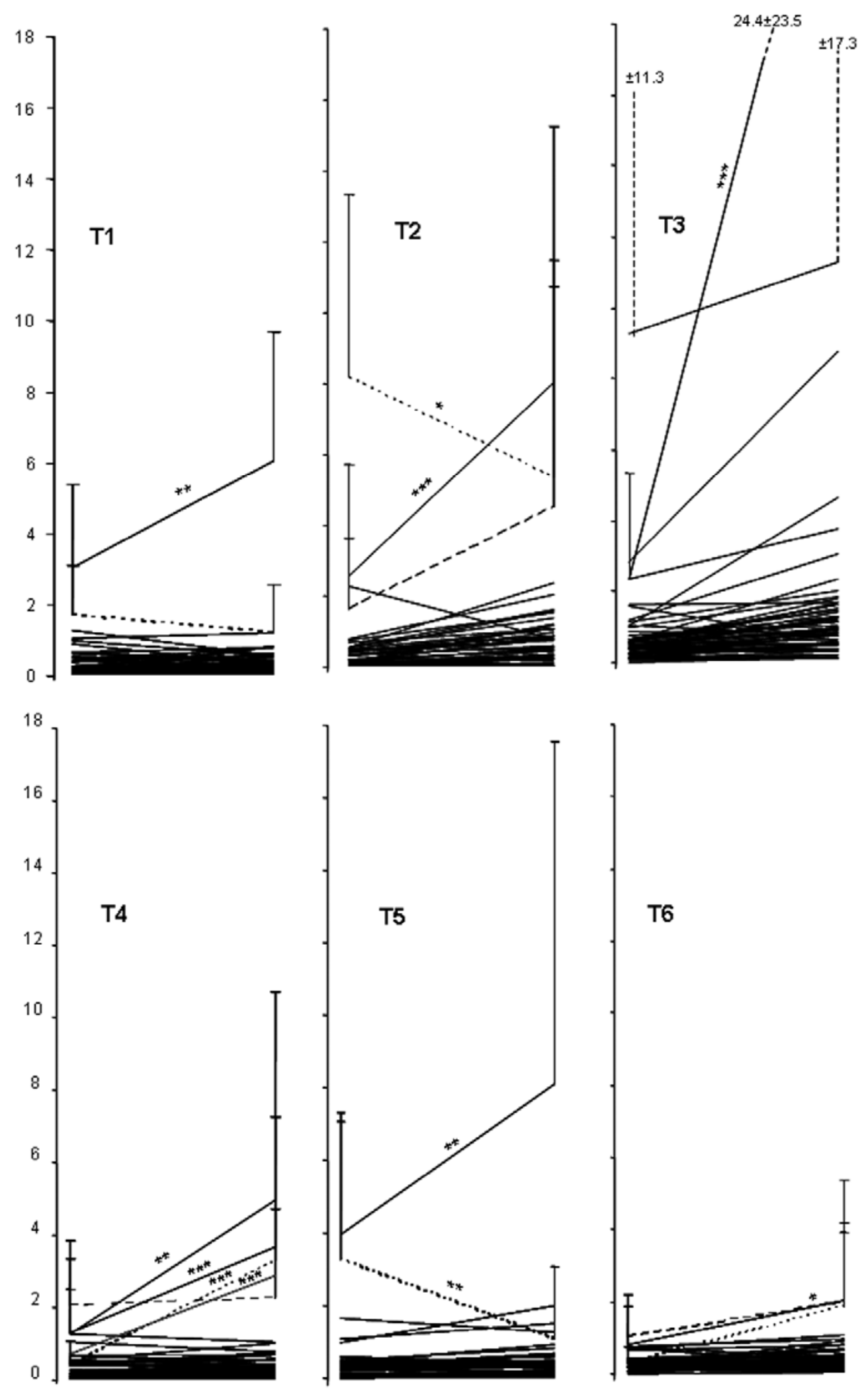

Figure 4. Mean \pm standard deviation of number of trigger actuations performed by each individual before and after fasting period (day 27-80 and day 103-142 periods) in $\mathrm{T}_{\text {low }}(\mathrm{CV} \sim 10 \%$ : low $\mathrm{CV}$ of weight) (Tanks 1, 2, 3) and $\mathrm{T}_{\text {high }}(\mathrm{CV} \sim 20 \%$ : high $\mathrm{CV}$ of weight) (Tanks 4, 5, 6) groups. Significant 
differences before and after fasting are represented by an asterisk (Mann-Whitney test):* $\mathrm{P}<0.05,{ }^{* *}$ $\mathrm{P}<0.01, * * * \mathrm{P}<0.001$

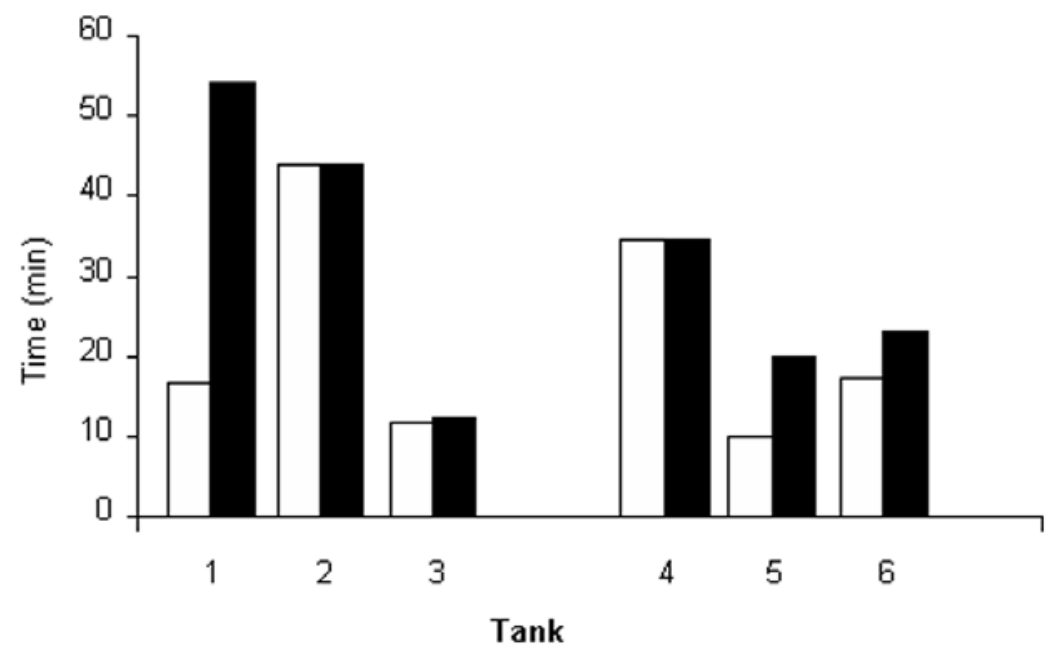

Figure 5. Latency time taken by any fish (black bars) to perform the first actuations after the fasting period (at day 103) in $\mathrm{T}_{\text {low }}\left(\mathrm{CV} \sim 10 \%\right.$ : low $\mathrm{CV}$ of weight) (Tanks 1, 2, 3 and $\mathrm{T}_{\text {high }}(\mathrm{CV} \sim 20 \%$ : high $\mathrm{CV}$ of weight) (Tanks $4,5,6)$ groups. In white bars: latency time taken by fish that were high-triggers before fasting. 
Table 1. $\mathrm{N}=24$, mean \pm standard deviation of blood plasma variables before fasting (Day 82), after fasting (Day 102) and at the end of the experiment (Day 144). Letters following means indicate statistical differences between sampling dates, means not sharing a common letter are significantly different and no letter means no significant difference. ${ }^{*} \mathrm{P}<0.05,{ }^{* *} \mathrm{P}<0.01, * * * \mathrm{P}<0.001$

\begin{tabular}{|c|c|c|c|c|}
\hline & Day 82 & Day 102 & Day 144 & \\
\hline $\mathrm{Ph}$ & $7.2 \pm 0.0^{\mathrm{a}}$ & $7.2 \pm 0.1^{\mathrm{a}}$ & $6.9 \pm 0.2^{b}$ & $* * *$ \\
\hline $\mathrm{pCO}_{2}(\mathrm{~mm} \mathrm{hg})$ & $31.3 \pm 5.9^{\mathrm{a}}$ & $21.9 \pm 2.9^{b}$ & $57.8 \pm 12.1^{\mathrm{c}}$ & $* * *$ \\
\hline $\mathrm{pO}_{2}(\mathrm{~mm} \mathrm{hg})$ & $36.9 \pm 11.9^{\mathrm{a}}$ & $32.4 \pm 13.3^{\mathrm{a}}$ & $14.1 \pm 11.4^{\mathrm{b}}$ & $* * *$ \\
\hline $\mathrm{BE}\left(\mathrm{mmol} \mathrm{l}^{-1}\right)$ & $-15.4 \pm 2.4$ & $-18.9 \pm 1.9$ & $-19.5 \pm 5.2$ & \\
\hline $\mathrm{HCO}_{3}\left(\mathrm{mmol} \mathrm{l}^{-1}\right)$ & $12.5 \pm 1.9^{\mathrm{a}}$ & $8.9 \pm 1.2^{b}$ & $12.3 \pm 2.9^{\mathrm{a}}$ & $* * *$ \\
\hline $\mathrm{TCO}_{2}\left(\mathrm{mmol} \mathrm{l}^{-1}\right)$ & $13.4 \pm 2.2^{\mathrm{a}}$ & $9.6 \pm 1.2^{\mathrm{b}}$ & $14.1 \pm 2.7^{\mathrm{a}}$ & $* * *$ \\
\hline $\mathrm{sO}_{2}(\%)$ & $57.6 \pm 18.6^{\mathrm{a}}$ & $47.7 \pm 22.2^{\mathrm{a}}$ & $11.4 \pm 18.3^{\mathrm{b}}$ & $* * *$ \\
\hline $\mathrm{Na}\left(\mathrm{mmol} \mathrm{l}^{-1}\right)$ & $158.2 \pm 9.3^{\mathrm{a}}$ & $150.0 \pm 29.6^{\mathrm{a}}$ & $168.0 \pm 8.7^{\mathrm{b}}$ & $* * *$ \\
\hline $\mathrm{K}\left(\mathrm{mmol} \mathrm{l} \mathrm{l}^{-1}\right)$ & $4.3 \pm 0.9^{\mathrm{a}}$ & $4.1 \pm 0.6^{\mathrm{a}}$ & $5.9 \pm 1.4^{b}$ & $* * *$ \\
\hline $\mathrm{iCA}\left(\mathrm{mmol}^{-1}\right)$ & $1.1 \pm 0.3$ & $0.9 \pm 0.4$ & $1.4 \pm 0.3$ & \\
\hline Glucose $\left(\mathrm{mg} \mathrm{dl}^{-1}\right)$ & $133.5 \pm 46.5^{\mathrm{a}}$ & $72.5 \pm 16.4 b^{b}$ & $354.8 \pm 74.1^{\mathrm{c}}$ & $* * *$ \\
\hline Hct (\% PCV) & $26.1 \pm 5.0^{\mathrm{a}}$ & $21.2 \pm 3.4^{\mathrm{b}}$ & $29.9 \pm 4.7^{\mathrm{a}}$ & $* * *$ \\
\hline $\mathrm{Hb}\left(\mathrm{mmol} \mathrm{l}^{-1}\right)$ & $8.8 \pm 1.7^{\mathrm{a}}$ & $7.2 \pm 1.2^{\mathrm{b}}$ & $10.2 \pm 1.6^{\mathrm{a}}$ & $* * *$ \\
\hline
\end{tabular}

